\title{
IMPLEMENTASI AKSIOLOGIS DALAM BUKU SMA KELAS X PELAJARAN BAHASA INDONESIA KURIKULUM 2013
}

\author{
Ridwan $^{1}$, Abdul Rosid ${ }^{2}$ \\ ${ }^{1}$ Universitas Negeri Yogyakarta \\ ${ }^{2}$ Universitas Trunojoyo Madura \\ Email: 1rid.wn@yahoo.com, 2abdulrosid1045@gmail.com
}

\begin{abstract}
Abstrak
Aksiologis merupakan cabang filsafat yang membahas teori-teori nilai dan berusaha mendeskripsikan mengenai kebaikan dan perilaku yang baik. Bagian dari aksiologi adalah etika dan estetika. Fokus pembahasan adalah bagaimanakah implementasi landasan aksiologis dalam pembelajaran Bahasa Indonesia kurikulum 2013 di sekolah menengah atas. Dengan demikian, akan dapat diketahui bagaimanakah landasan aksiologis jika di sematkan di dalam buku ajar bahasa Indonesia untuk SMA kelas X. Kemudian, baik guru, pengembang dapat menyesuaikan kebutuhan pengimplementasian landasan aksiologis dalam kegiatan pembelajaran maupun mengembangkan bahan ajar terbaru yang lebih baik. Adapun yang menjadi objek penelitian ini adalah isi buku pelajaran bahasa Indonesia kurikulum 2013 edisi revisi tahun 2014 untuk siswa SMA kelas 10 terbitan Kementerian Pendidikan Dan Kebudayaan Republik Indonesia. Metode penelitian yang digunakan yaitu deskriptif kualitatif. Adanya implementasi landasan aksiologis yang berupa nilai-nilai moral dan etika perilaku manusia serta nilai estetika dalam penelitian ini dapat diketahui di dalam pengantar pelajaran, materi teks, gambar, kegiatan dan tugas-tugas, serta identifikasi hasil capaian atau tabel penilaian. Fokus nilai moral dan perilaku di dalamnya dimuat dan dikelompokkan ke dalam beberapa nilai yang umumnya dipakai dalam kurikulum berkarakter yakni kurikulum 2013. Selain itu, nilai estetika dan kesenian yang divisualisasikan ke bentuk tipografi, ilustrasi, dan tata letak di dalamnya berperan sebagai pendukung yang baik di dalamnya.
\end{abstract}

Kata Kunci: Implementasi, Landasan Aksiologis, Bahan Ajar, Bahasa Indonesia.

\section{PENDAHULUAN}

Di era global ini, ancaman hilangnya karakter semakin tampak nyata. Peralihan Indonesia semula negara berkembang menjadi maju akan berdampak pada kemajuan teknologi informasi. Perkembangan teknologi sangat cepat membuat situs-situs video, gambar, dan cerita tidak senonoh mudah terakses melalui situs-situs peralihan, akibatnya nilai-nilai yang luhur tergerus oleh globalisasi, utamanya kesalahan dalam memahami makna kebebasan sebagai sebuah demokrasi dan rendahnya filosofi teknologi (Barnawi dan Arifin, 2012:14-15). Pernyataan dari Barnawi juga seirama dengan pernyataan Kurniawan (2013:17) yang mengungkapkan, saat ini kita tengah berada di pusaran hegemoni media, revolusi ilmu pengetahuan dan teknologi (iptek), yang tidak hanya mampu menghadirkan sejumlah kemudahan dan kenyamanan hidup bagi manusia modem, tetapi juga mengundang serentetan persoalan dan kekhawatiran. Kemajuan ilmu pengetahuan dan teknologi dapat mengurangi atau bahkan menihilkan nilai kemanusiaan atau yang disebut dehumanisasi.
Pendidikan karakter menjadi sangat penting dalam rangka membangun peradaban berbasis nilai. Secara umum banyak diketahui oleh khalayak guru bahwa kurikulum 2013 merupakan kurikulum yang mengedepankan nilai. Kurikulum 2013 mengusung tema: menghasilkan insan Indonesia yang produktif kreatif, inovatif, dan berkarakter, melalui penguatan sikap, keterampilan, dan pengetahuan secara tereintegrasi. Jelas sekali melalui tema itu, tujuan yang dibentuknya kurikulum 2013 untuk mengarahkan insan di Indonesia berbasis nilai dalam rangka merealisasikan tujuan pendidikan nasional dan undang-undang dasar NKRI yaitu mencerdaskan kehidupan bangsa.

Dari ulasan tersebut, fokus permasalahan penelitian ini adalah bagaimanakah implementasi landasan aksiologis dalam bahan pembelajaran bahasa Indonesia di sekolah menengah atas. Tujuannya adalah sebagai daya dukung untuk menerapkan tercapainya pembelajaran dan pemerolehan informasi yang nyaman terhadap siswa atau guru. Dengan demikian, akan dapat diketahui bagaimanakah landasan aksiologis jika di sematkan di dalam buku ajar bahasa Indonesia 
untuk SMA kelas X. Kemudian, baik guru, pengembang dapat menyesuaikan kebutuhan pengimplementasian landasan aksiologis dalam kegiatan pembelajaran maupun mengembangkan bahan ajar terbaru yang lebih baik. Adapun yang menjadi objek penelitian adalah isi buku pelajaran bahasa Indonesia kurikulum 2013 edisi revisi tahun 2014 untuk siswa SMA kelas 10 terbitan Kementerian Pendidikan Dan Kebudayaan Republik Indonesia.

Aksiologis merupakan cabang filsafat yang membahas teori-teori nilai dan berusaha mendeskripsikan mengenai kebaikan dan perilaku yang baik. Bagian dari aksiologi adalah etika dan estetika. Etika menunjuk pada kajian filsafat tentang nilai-nilai moral dan perilaku manusia. Estetika berkaitan dengan kajian nilainilai keindahan dan seni. (Rukiyati dan Zuchdi, 2016:35). Dalam kegiatan pembelajaran, kebiasaan etika (nilai-nilai moral, karakter, dan perilaku manusia) maupun estetika perlu dimuat dengan tujuan untuk menanamkannya terhadap peserta didik. Penanaman etika dimaksudkan untuk membentuk karakter seseorang yang mengarah pada hal-hal positif. Penanaman etika yang baik tentunya dapat membangun watak, sikap, dan perilaku yang memperkuat softskill untuk menanamkan kebiasaan-kebiasaan baik.

Etika merujuk pada kajian filsafati tentang nilai moral dan perilaku manusia. Etika diklasifikasikan menjadi tiga bidang studi, yakni etika deskriptif, normatif, dan meta etika (Zaprulkhan, 2016 : 89). Etika deskriptif menjelaskan kesadaran, keyakinan, dan pengalaman moral secara deskriptif. Etika deskriptif dibagi menjadi dua bagian: pertama, sejarah moral, yang meneliti cita-cita, aturan, dan norma moral yang diberlakukan dalam kehidupan manusia pada kurun waktu tertentu atau mencakup beberapa bangsa; kedua, fenomenologi moral, berupaya menemukan arti dan makna moralitas dari berbagai fenomena moral yang ada (Zaprulkhan, 2016 : 90).

Etika normatif merupakan sistem yang memberikan petunjuk atau penuntun dalam mengambil keputusan yang menyangkut baik dan buruk, benar dan salah. Etika normatif dibagi ke dalam dua teori besar, yakni: pertama, etika teleologi, teori ini memiliki pandangan bahwa tindakan dapat dinilai etis dilihat dari konsekuensi dan akibatnya; kedua, etika deontologis, teori ini mengukur baik tidaknya satu perbuatan hanya berdasarkan maksud si pelaku. Suatu tindakan dapat menjadi wajar atau benar walaupun hal itu tidak membawa pada akibat baik karena pelaku melakukan tindakan dengan dasar kewajiban atau niat baik (Zaprulkhan, 2016 : 92).

Meta etika hadir pada abad ke 20 sebagai suatu studi terhadap disiplin etika. Metika secara khusus menyelidiki dan menetapkan arti serta makna istilah-istilah normatif yang diungkapkan lewat pernyataan etis dengan tujuan membenarkan atau menyalahkan suatu tindakan (Zaprulkhan, 2016 : 93).

Selain berfokus pada nilai etika, pada umumnya nilai keindahan dan seni dipengaruhi oleh cara pandang visualisasi. Unsur dasar yang harus ada pada sebuah produk adalah tipografi, ilustrasi, dan tata letak. Ketiga unsur dasar tersebut pada umumnya ada dalam produk untuk membuat nilai tambah yakni keindahan dan keserasian dalam hal ini adalah estetika. Ur (2009:193 dalam Syamsi, 2013:82) memberikan petunjuk dalam penulisan dan pengembangan bahan ajar agar materi lebih jelas dan menarik, harus menggunakan tata letak, ilustrasi, dan gambar yang seimbang dan bervariasi. Namun, menurut Sunarto (2001:7) huruf, menjadi menjadi satu-satunya visualisasi yang efektif visualisasi (ilustrasi, foto, efek grafika lain).

\section{METODE}

Metode penelitian yang digunakan adalah deskriptif kualitatif. Metode ini di pilih agar mudah mengidentifikasi, menganalisis, dan mendeskripsikan data yang diperoleh. Data dalam penelitian ini berupa kutipan teks yang berkaitan dengan nilai-nilai etika dan estetika yang menjadi bagian aksiologis. Teknik pengumpulan datanya adalah studi kepustakaan. Adapun langkah-langkahnya dalam penelitian ini adalah sebagai berikut, mengidentifikasi dengan cara (1) membaca, mengamati isi buku, (2) menyisihkan bagian-bagian tertentu dalam buku ajar yang berkaitan dengan etika maupun estetika. Menganalisis mencocokkan lebih detail terkait dengan etika dan estetik. Mendeskripsikan data sesuai dengan permasalahan yang dianalisis.

\section{HASIL DAN PEMBAHASAN}

Muatan landasan aksiologis yang berfokus pada nilai-nilai moral dan etika perilaku manusia dalam isi buku pelajaran bahasa Indonesia kurikulum 2013 edisi revisi 2014 untuk SMA kelas 10, dimuat ke dalam bentuk pengantar pelajaran, materi teks, gambar, kegiatan dan tugas-tugas, serta identifikasi hasil 
capaian atau tabel penilaian. Selain itu, yang menjadi pendukung fokus nilai moral dan perilaku manusia pada buku tersebut adalah nilai estetika yang divisualisasikan ke bentuk tipografi, ilustrasi, dan tata letak.

\section{Nilai Moral dan Perilaku Manusia}

\section{Jujur}

Nilai jujur ditunjukkan pada pelajaran 5 kegiatan 1 pembangunan konteks dan pemodelan teks negosiasi yang berjudul "negosiasi antara karyawan dan pengusaha. Melalui teks dialog antara karyawan dan pengusaha terdapat beberapa pertanyaan dari wakil perusahaan yang dijawab jujur oleh wakil karyawan. Pertama, jawaban tentang pertanyaan mengenai alasan melakukan demonstrasi. Kedua, mengenai jalan tengah yang akan diambil dalam mengatasi masalah.

2. Toleransi

Nilai toleransi mengenai perbedaan pendapat ditemukan melalui dialog antara resepsionis, david, dan manager mengenai kesalahpahaman. Dengan mengamati inti permasalahannya dapat disimpulkan bahwa sang manager bertoleransi terhadap pendapat david yang menunjukkan fakta yang sebenarnya. Hal tersebut dapat dilihat pada pelajaran 5 kegiatan 2 tugas 5 memahami teks kesalahpahaman.

\section{Disiplin}

Implementasi nilai disiplin dalam buku pelajaran bahasa Indonesia kelas 10 berada dalam pelajaran 2 proses menjadi warga yang baik kegiatan 1 dan 2. Di dalamnya berisikan tentang nilai disiplin yang diterapkan melalui membaca teks prosedur tentang tilang, mendiskusikan langkah-langkah dalam teks prosedur, memahami struktur teks prosedur, memahami unsur kebahasaan dalam teks prosedur, menganalisis bagian-bagian teks prosedur, membaca teks cara mengurus SIM, menyusun langkah-langkah penerimaan siswa baru, membaca teks prosedur pengurusan KTP, menyusun kembali urutan kalimat dalam teks prosedur, memahami prosedur membaca puisi.

Disiplin Tindakan yang menunjukkan perilaku tertib dan patuh pada berbagai ketentuan dan peraturan. Aturan berlalu lintas misalnya dituangkan ke dalam mengenai prosedur tentang tilang sebagai sanksi melanggar ketertiban berlalu lintas. Mengurus SIM pun merupakan aturan yang diberlakukan terhadap setiap pengemudi yang telah memenuhi kewajiban umur yang ditetapkan.
Gambar polisi lalu lalu lintas juga ditampilkan dalam buku ajar yang menunjukkan kegiatan polisi dalam menertibkan pengguna lalu lintas. Adapun keterangan teks yang menyertai gambar berjudul "apa yang harus Anda lakukan jika ditilang? Salah satunya adalah berupa penilangan yang menjadi sanksi pelanggaran lalu lintas, kutipannya adalah "Di Indonesia banyak pengendara kendaraan bermotor. Jika pengendara melakukan pelanggaran, tentu pihak berwajib akan menilangnya." (halaman 37).

\section{Kerja Keras}

Nilai kerja keras dapat ditemukan dalam pelajaran 5 kegiatan 2 tugas 3 membaca teks "ekspor kain sarung ke negeri Yaman. Di dalamnya dapat dibuktikan dengan gambaran kesuksesan Haji Sultoni dalam menjalankan usaha kain sarung. Beliau bekerja keras dalam memproduksi kain sarung yang merupakan hasil kerajinan alat tenun bukan mesin. Berikut kutipannya,

"Kain sarung asal Indonesia, menurut $H$. Sultoni (53), sangat digemari oleh orangorang Somalia, Saudi Arabia, dan Yaman. Melihat potensi pasar kain sarung yang cukup besar di Kawasan Timur Tengah itu, pada tahun 2005 ia mengekspor kain sarung ke kawasan tersebut.

Menurut pemilik perusahaan tenun tradisional asal Desa Wanarejan Utara, Kecamatan Taman, Kabupaten Pemalang, Jawa Tengah ini, kain sarung yang ia produksi merupakan hasil kerajinan alat tenun bukan mesin (ATBM)."

Selain gambaran kerja keras dalam teks di atas, ada juga di dalam pelajaran 4 kegiatan 4 tugas 4 membaca teks "anekdot hukum peradilan" halaman 102. Hal itu ditunjukkan bahwa terdapat seorang tokoh yang rajin dan tekun sebagai upaya bentuk kerja keras dalam berdagang. Hal itu dapat dibuktikan dalam kutipan berikut ini.

"Pada zaman dahulu di suatu negara (yang pasti bukan negara kita) ada seorang tukang pedati yang rajin dan tekun. Setiap pagi dia membawa barang dagangan ke pasar dengan pedatinya. Suatu pagi dia melewati jembatan yang baru dibangun."

\section{Kreatif}

Wujud kreatif dalam buku pelajaran bahasa Indonesia kurikulum 2013 kelas 10 SMA tertera 
April 2020 Jurnal Pendidikan Bahasa dan Sastra Indonesia

melalui bentuk harapan terhadap pencapaian siswa, yang bertujuan untuk membentuk daya berpikir kreatif. Hal itu dapat dilihat dari kutipankutipan berikut ini,

Pembelajaran teks ini dimaksudkan untuk membantu peserta didik mengembangkan wawasan pengetahuan melalui kegiatan meneroka alam semesta agar terampil berpikir kritis dan kreatif serta mampu bertindak efektif menyelesaikan permasalahan dalam kehidupan nyata. (pelajaran 1:2)

Pembelajaran teks ini dimaksudkan untuk membantu peserta didik mengembangkan wawasan pengetahuan mengenai kewarganegaraan. Tujuannya adalah agar peserta didik terampil berpikir kritis dan kreatif serta mampu bertindak efektif menyelesaikan permasalahan dalam kehidupan nyata. (pelajaran 2:35)

Pembelajaran teks ini dimaksudkan untuk membantu peserta didik mengembangkan wawasan pengetahuan mengenai kebebasan berpendapat di forum ekonomi dan politik. Tujuannya adalah agar peserta didik terampil berpikir kritis dan kreatif serta mampu bertindak efektif menyelesaikan permasalahan dalam kehidupan nyata. (pelajaran 3:69)

Pembelajaran teks ini dimaksudkan untuk membantu peserta didik mengembangkan wawasan pengetahuan mengenai kritik dan humor dalam layanan publik. Tujuannya adalah agar peserta didik terampil berpikir kritis dan kreatif serta mampu bertindak efektif menyelesaikan permasalahan dalam kehidupan nyata. (pelajaran 4:98).

Pembelajaran teks ini dimaksudkan untuk membantu peserta didik mengembangkan wawasan pengetahuan mengenai negosiasi. Tujuannya adalah agar peserta didik terampil berpikir kritis dan kreatif serta mampu bertindak efektif menyelesaikan permasalahan dalam kehidupan nyata. (pelajaran 5:121)

Dari beberapa kutipan di atas, daya berpikir kreativitas siswa diharapkan dalam bertindak dan menyelesaikan permasalahan dalam kehidupan nyata misalnya, melalui kegiatan meneroka alam semesta, mengembangkan wawasan pengetahuan mengenai kewarganegaraan, mengembangkan wawasan pengetahuan mengenai kebebasan berpendapat di forum ekonomi dan politi, mengembangkan pengetahuan mengenai kritik dan humor dalam layanan publik, dan mengembangkan wawasan pengetahuan mengenai negosiasi.

Selain menjadi tujuan pelajaran, tindakan kreatif juga menjadi faktor penilaian yang yang amat baik (dari yang terendah dimulai, kurang, baik, dan amat baik) dalam aspek alat bantu visual penilaian presentasi lisan di tabel halaman 209.

6. Mandiri

Sikap tidak mudah bergantung kepada orang lain atau mandiri diwujudkan dalam buku ajar dengan berupa bentuk instruksi kerja mandiri. Instruksi itu dapat diketahui dari pelajaran 1 kegiatan 3 kerja mandiri membangun teks laporan hasil observasi, teks prosedur (pelajaran 2 kegiatan 3), teks eksposisi (pelajaran 3 kegiatan 3), teks anekdot (pelajaran 4 kegiatan 3), teks negosiasi (pelajaran 5 kegiatan 3), dan terakhir kerja mandiri membangun berbagai jenis teks satu tema (pelajaran 6 kegiatan 3).

7. Demokratis

Cara berpikir, bersikap, dan bertindak yang menilai sama hak dan kewajiban dirinya dan orang lain adalah arti demokratis yang tertera nilainya dalam pelajaran 1 kegiatan 2 kerja sama membangun teks prosedur kompleks tugas 4 menceritakan ulang teks prosedur berjudul "tata cara pemilihan ketua RT dan wakil ketua RT. Di dalamnya dijelaskan mengenai hak para kepala keluarga untuk mengusulkan nama calon ketua dan wakil ketua RT di lingkungan RT setempat. Selanjutnya menyelenggarakan pemilihan dengan mengutamakan musyawarah untuk mufakat. Terakhir melaporkan berita acara hasil pemilihan kepada camat melalui lurah untuk mendapatkan pengesahan.

8. Rasa Ingin Tahu

Sikap atau tindakan yang mencerminkan rasa ingin tahu dituangkan ke dalam sebuah puisi berjudul "seonggok jagung" karya WS Rendra. Yang menanyakan kegunaan pendidikan yang ditanyakan hingga dua kali dalam puisinya. Berikut kutipannya,

"Aku bertanya

Apakah gunanya pendidikan,

bila hanya akan membuat seseorang menjadi asing di tengah kenyataan persoalannya? 
Apakah gunanya pendidikan bila hanya mendorong seseorang

menjadi layang-layang di ibu kota, menjadi sekrup-sekrup di Schlumberger, Freeport, dan sebagainya,

kikuk pulang ke daerahnya?"

Selain itu, rasa keingintahuan terhadap parameter ketercapaian siswa dalam setiap materi ditunjukkan oleh beberapa pertanyaan dalam setiap tugas, setiap kegiatan dalam setiap pelajaran di buku bahasa Indonesia kelas 10 SMA kurikulum 2013. Misalnya, tugas 1 menghayati pesan puisi "seonggok jagung" terdapat delapan pertanyaan yaitu,

(1) Sajak W.S. Rendra di atas menggambarkan seorang pemuda yang hanya Tinggal berdiam. Ia terkungkung di dalam rumah sehingga tidak bebas bergerak dan berekspresi di luar rumah. Setelah membaca sajak tersebut, bandingkan isinya dengan pengalaman dan kesempatan kalian berpendapat dalam kehidupan sehari-hari!

(2) Bagaimanakah kesempatan kalian untuk berpendapat di rumah?

(3) Bagaimanakah kesempatan kalian untuk berpendapat di masyarakat?

(4) Setujukah kalian bahwa pendidikan sekolah yang sekarang diselenggarakan di negara tercinta ini secara terus-menerus sedang mengembangkan kesempatan untuk berpendapat bagi siswa?

(5) Sebagai siswa, apakah kalian merasa bebas untuk berpendapat di sekolah?

(6) Dengan cara apakah biasanya kalian mengajukan pendapat di sekolah? Siapa yang biasanya mendengarkan pendapat kalian di sekolah?

(7) Pada saat mengikuti pelajaran di kelas, kapan kalian diberi kesempatan untuk berpendapat?

(8) Apakah pendapat kalian sering disetujui atau ditolak? Tahukah kalian mengapa pendapat kalian disetujui atau ditolak?

Begitu pula dalam tugas 2 membaca teks eksposisi tentang ekonomi Indonesia, delapan pertanyaan menyertai teks yang berjudul "Ekonomi Indonesia akan melampaui Jerman dan Inggris". Adapun pertanyaan yang menyertai adalah sebagai berikut,

(1) Menurut kalian, negara manakah yang memiliki ekonomi yang paling bagus di dunia dan negara manakah yang memiliki ekonomi yang paling buruk?
(2) Apabila dibandingkan dengan negara lain, ekonomi Indonesia berada pada urutan berapa?

(3) Mungkinkah Indonesia memiliki ekonomi yang setara dengan ekonomi negara maju?

(4) Syarat apakah yang harus dipenuhi agar ekonomi Indonesia menjadi setara dengan ekonomi negara maju?

(5) Apakah yang ditempuh oleh Pemerintah agar syarat itu terpenuhi?

(6) Apakah yang seharusnya ditempuh oleh setiap warga agar ekonomi Indonesia maju?

(7) Apakah yang seharusnya dilakukan oleh sekolah agar ekonomi Indonesia maju?

(8) Apakah yang dapat kalian lakukan agar ekonomi Indonesia maju?

9. Semangat Kebangsaan

Upaya mementingkan bangsa dan negara di atas kepentingan diri sendiri salah satunya dengan langkah membenahi perekonomian Indonesia yang dicerminkan dalam tugas 2 membaca teks eksposisi tentang ekonomi Indonesia. Teks berjudul "ekonomi Indonesia akan melampaui Jerman dan Inggris" halaman 73 yang dapat diketahui melalui kutipan berikut.

"Upaya melakukan pendalaman pasar keuangan (Financial deepening) menjadi penting dalam memberikan ragam pilihan investasi bagi para investor.

Di sisi lain, pembenahan di sektor riil dan infrastruktur perlu terus dilakukan secara serius guna mendukung arah untuk menjadikan ekonomi Indonesia yang

terbesar di Asia Tenggara.

Saat ini, pertumbuhan ekonomi Indonesia yang berada pada kisaran 5 persen hingga 6 persen, apabila dapat terus dipertahankan, akan menambah jumlah masyarakat kelas menengah hingga 90 juta orang dengan pendapatan per kapita lebih dari 3.600 dolar AS. Apabila kita mampu mendorong pertumbuhan hingga 7 persen, jumlah itu bertambah lagi dengan masyarakat menengah mencapai 170 juta orang."

Dari penggalan teks tersebut dapat diketahui bahwa upaya menumbuhkan pertumbuhan ekonomi Indonesia adalah dengan melakukan pendalaman pasar keuangan serta pembenahan di sekotor riil dan infrastruktur.

Selain bentuk teks, semangat kebangsaan juga ditampilkan dalam bentuk gambar yaitu, 
gambar tokoh nasional Indonesia yang sedang berpidato (gambar 3.7, 3.8 halaman 96). Kemudian, gambar sidang pembahasan ekonomi Indonesia (gambar 3.3 halaman 73), paspor yang dikeluarkan oleh pemerintah Indonesia (gambar 2.8 halaman 63).

\section{Cinta Tanah Air}

Cinta tanah air yang menunjukkan peduli dan setia menggunakan bahasa Indonesia adalah ciri khas utama buku pelajaran bahasa Indonesia kurikulum 2013. Buku pegangan untuk siswa tersebut berbahasa Indonesia secara menyeluruh mulai awal hingga akhir.

Selain itu, kegiatan 2 kerja sama membangun teks eksposisi, tugas 1 memahami teks eksposisi tentang politik bahasa ASEAN, terdapat suatu teks yang membahas mengenai politik bahasa di negara-negara ASEAN. Dalam pengantar kegiatan 2, nilai cinta tanah air yang mencerminkan politik ekonomi dan bahasa ditunjukkan secara rinci nilai tersebut. Berikut kutipannya,

"Perlu kalian ketahui bahwa kebijakan politik tidak hanya terkait dengan masalah ekonomi, tetapi juga masalah bahasa. Dengan kata lain, kebijakan bahasa tidak terlepas dari kemauan politik sebuah negara. Penetapan bahasa Indonesia sebagai bahasa nasional adalah contoh kebijakan politik yang tepat. Ternyata kebijakan itu berakar pada kemauan politik dari para pemuda Indonesia yang dimotori oleh M. Tabrani pada tanggal 2 Mei 1926, kemudian gerakan politik pemuda Indonesia itu memuncak pada tanggal 28 Oktober 1928 ketika mereka mencetuskan Sumpah Pemuda."

\section{Menghargai Prestasi}

Bentuk reward dalam objek penelitian ini adalah apresiasi yang dideskripsikan dalam pengantar atau sambutan dari Kementerian Pendidikan dan Kebudayaan Republik Indonesia, dan Kepala Pembinaan dan Pengembangan Bahasa Indonesia. Hal itu menunjukkan bahwa terdapat penghargaan yang tertulis di dalamnya bagi pengembangan buku teks bahasa Indonesia kurikulum 2013 edisi revisi ini.

Bentuk menghormati dan menghargai prestasi tugas 5 teks membaca puisi di atas pentas halaman 61 dalam mendorong untuk menghasilkan sesuatu dan menghormati keberhasilan orang lain. Berikut kutipannya,

\begin{abstract}
"Kuasailah pentas dan penonton dengan mengarahkan pandangan ke segala penjuru sambil memberikan penghormatan kepada mereka dengan cara menganggukkan kepala."
\end{abstract}

Dari kutipan tersebut, menghormati orang lain sesuai dengan deskripsi nilai menghargai prestasi dapat disikapi dengan cara memberikan penghormatan walau dengan cara menganggukkan kepala saja. Hal tersebut dilakukan dalam prosedur awal maupun akhir sebuah pementasan karya sastra berupa puisi.

12. Bersahabat/ Komunikatif

Pelajaran kelas 10 Kegiatan 2 materi Kerja Sama Membangun Teks Laporan Hasil Observasi merupakan implementasi dari nilai bersahabat/komunikatif. Implementasi nilai itu bertujuan untuk bersama-sama melakukan kegiatan membaca teks "karbon", meringkas isi teks laporan, menata struktur teks laporan, menanggapi isi teks laporan, mengolah data teks laporan, menginterpretasi teks laporan.

13. Cinta Damai

Nilai cinta damai yang berarti sikap dan perilaku yang mencerminkan suasana damai, aman, tenang, dan nyaman atas kehadiran dirinya dalam komunitas atau masyarakat tertentu dituangkan ke dalam pelajaran 5 seni bernegosiasi dalam kewirausahaan, kegiatan 3 kerja mandiri membangun teks negosiasi, tugas 3. Bernegosiasi untuk memecahkan konflik memang salah satu kegiatan yang penting dalam upaya perdamaian, bebas konflik. Penuangan nilai ini berupa perintah tugas yang diberlakukan sesuai dengan petunjuk dengan tiga tahapan untuk mengamati kegiatan negosiasi di sekitar dan membuat dialog struktur teks bernegosiasi dan diperagakan di dalam kelompok.

14. Gemar Membaca

Adapun implementasi gemar membaca tidak dicerminkan ke dalam wacana, namun dicerminkan ke perintah sebagai bentuk awal untuk proses kegiatan memahami, membedah menganalisis materi teks bacaan. Hal itu ditunjukkan dalam berikut ini. Pelajaran 1, membaca teks makhluk hidup di bumi ini, membaca teks "Karbon"; pelajaran 2, membaca teks prosedur tentang tilang, membaca teks cara mengurus SIM; Pelajaran 3, membaca teks eksposisi tentang ekonomi Indonesia, membaca dualisme argumentasi dalam teks eksposisi; Pelajaran 4, membaca teks anekdot hukum peradilan, membaca teks anekdot dalam puisi; 
dan Pelajaran 5, membaca teks ekspor kain sarung ke negeri Yaman.

Beberapa perintah membaca dalam penugasan yaitu, (1) halaman 2, bacalah puisi berikut (berjudul burung-burung enggan bernyanyi lagi) dengan seksama, (2) halaman 4 , Carilah buku yang berisi laporan tentang keindahan alam Indonesia. Bacalah buku itu, lalu tuliskanlah hasil baca buku kalian. (3) halaman 4, Bacalah teks pendek yang berjudul "Makhluk di Bumi Ini" berikut. (4) halaman 13, Bacalah teks pendek yang berjudul "Sistem Peredaran Darah Manusia" berikut ini. (5) halaman 15, Bacalah teks laporan tentang harimau berikut ini.

\section{Peduli Lingkungan}

Buku Bahasa Indonesia kelas 10 pembahasan peduli lingkungan, berada di dalam pelajaran 1 Gemar Meneroka Alam Semesta kegiatan 1 pembangunan konteks dan pemodelan teks laporan hasil observasi dengan dimulai dengan puisi berjudul "Burung-burung Enggan Bernyanyi Lagi" karya Mh. Surya Permana yang bertema lingkungan. Di dalamnya terdapat pesan yang disampaikan yaitu, "Alam semesta adalah ciptaan Tuhan Yang Maha Esa yang diperuntukkan bagi manusia agar dijaga dan dipelihara. Sebagai ciptaan Tuhan, alam tidak boleh di rusak oleh manusia." (Kemendikbud, 2014:2)

Tugas membaca, Teks "Makhluk di Bumi ini". Kemudian dilanjutkan dengan membedah struktur teks laporan tersebut, mengamati teks laporan yang ideal, memahami kalimat definisi dalam teks laporan. Dengan adanya teks tersebut melalui tahapan tugas yang diberikan siswa akan dapat memiliki wawasan luas mengenai lingkungan dengan mengetahui klasifikasi makhluk menjadi kelompok benda hidup dan mati. Kelompok hewan dan tumbuhan yang saling berkaitan satu dengan yang lainnya membentuk rantai kehidupan untuk dijaga keberlangsungan dan diperoleh manfaatnya bagi kehidupan manusia.

Selain bentuk teks, divisualisasikan juga gambar satwa hewan langka di Indonesia yang terancam punah, misalnya gambar 6.1 komodo sebagai salah satu hewan langka halaman 150 dan gambar 6.2 orang utan sebagai salah satu hewan langka halaman 153.

16. Peduli Sosial

Nilai peduli sosial yang diimplementasikan ke dalam buku ajar bahasa Indonesia kelas 10 yaitu terdapat pada pelajaran 6 teks dalam kehidupan nyata kegiatan 3 tugas 1 menemukan teks anekdot dalam fenomena sosial dan budaya. Dengan memanfaatkan tugas dalam menyajikan teks anekdot yang bermuatan kepedulian terhadap masyarakat di sekitar.

Selain itu, wujud kepedulian terdapat dalam tugas 1 halaman 109 menulis ulang teks anekdot yang berjudul "politisi blusukan banjir". Peduli membantu seseorang dengan untuk menyelamatkan nyawa seseorang adalah tindakan yang mencerminkan nilai sosial. Berikut kutipannya, "Untung regu penolong sangat sigap. Meskipun terseret cukup jauh, Darman masih bisa diselamatkan. Dia dibawa ke posko kesehatan dan dibaringkan di bangsal. Waktu itu semua bangsal penuh oleh orang pingsan. Darman kaget melihat orang yang ada di situ."

17. Tanggung Jawab

Buku Bahasa Indonesia kelas 10 pelajaran 1 kegiatan 3 pembahasan Kerja Mandiri Membangun Tes Laporan Hasil Observasi melalui pengelompokan tugas-tugas mencari contoh teks laporan dari berbagai sumber, menyunting teks laporan, mengabstraksi teks laporan, mengonversi teks laporan, dan memublikasikan teks laporan ke pemerintah setempat. Melalui prosedur buku ajar tersebut dimaksudkan agar setiap siswa akan dapat melakukan tanggung jawab terhadap tugas yang diberikan sesuai prosedur tertulis dalam buku ajar.

\section{Nilai-nilai Keindahan dan Seni}

\section{Tipografi}

Tipografi yang dalam keterangan, isi materi buku ditulis "Disusun dengan huruf Minion pro, 11 p" walau pada kenyataannya setelah di cocokkan dengan program Microsoft Office Word, ukurannya adalah $10 \mathrm{p}$. Urutan pelajaran 1, pelajaran 2, dst. Menggunakan jenis teks "MyriadPro-BoldCond 21 p" Nama pelajaran menggunakan jenis fon "Helvetica-Bold $50 \mathrm{p}$ ". Daftar isi, gambar, dan tabel menggunakan jenis huruf "Helvetica-Bold 28". Sedang judul setiap teks di dalam materi menggunakan jenis huruf "SegoeUI-Bold 13". Rata kanan dan kiri pada teks, rata kiri pada judul materi dan rata tengah pada judul teks.

2. Ilustrasi

Ilustrasi gambar terdapat 32, efek grafika, judul pelajaran, pengantar, daftar isi, daftar gambar, daftar tabel dan pendukung lain berwarna Jingga dan latar putih, hal ini tentu memberikan kesan desain formal dan elegan. Hal ini tentu sesuai dengan konsumen tujuan sekelas SMA. 


\section{Volume 5 No. 1 METALINGUA}

April 2020 Jurnal Pendidikan Bahasa dan Sastra Indonesia

\section{Tata letak}

Secara umum buku yang diamati dan dianalisis ini memiliki tata letak yang sangat baik. Isi di dalamnya terkesan penuh dan tidak boros ruang namun tidak ramai atau menumpuk.

\section{SIMPULAN}

Dari pembahasan, kesimpulan yang dapat diambil adalah adanya implementasi landasan aksiologis yang berupa nilai-nilai moral dan etika perilaku manusia serta nilai estetika dalam buku pelajaran bahasa Indonesia kurikulum 2013 edisi revisi 2014 untuk Sekolah Menengah Atas. Hal itu dapat diketahui di dalam pengantar pelajaran, materi teks, gambar, kegiatan dan tugas-tugas, serta identifikasi hasil capaian atau tabel penilaian. Fokus nilai moral dan perilaku di dalamnya dimuat dan dikelompokkan ke dalam beberapa nilai yang umumnya dipakai dalam kurikulum berkarakter yakni kurikulum 2013.

Selain itu, yang menjadi pendukung fokus nilai moral dan perilaku manusia pada buku tersebut adalah nilai estetika yang divisualisasikan ke bentuk tipografi yang lebih mendominasi adalah teks minion pro yang lebih formal. Ilustrasi yang digunakan di dalam buku ajar tersebut sangat berkesan, dengan warna Jingga berlatar putih terkesan lebih formal dan elegan. Terakhir, tata letak yang digunakan rapi, dan pas.

\section{REFERENSI}

Barnawi dan Arifin, M. 2012. Strategi dan kebijakan pembelajaran pendidikan karakter. Yogyakarta. Ar-Ruzz Media.

Kemendikbud. 2014. Bahasa Indonesia Ekspresi diri dan akademik. Jakarta: kemendikbud.

Kemdiknas. 2010. Pendidikan Karakter Terintegrasi dalam Pembelajaran di Sekolah Menengah Pertama. Jakarta: Direktorat PSMP Kemdiknas.

Kurniawan, Syamsul. 2013. Pendidikan Karakter: Konsepsi dan Implementasinya secara terpadu di lingkungan keluarga, sekolah, perguruan tinggi, dan masyarakat. Yogyakarta: Ar-Rus Media

Kristanto, M. 2014. pemanfaatan cerita rakyat sebagai penanaman etika untuk membentuk pendidikan karakter bangsa. Mimbar Sekolah Dasar (Universitas Pendidikan Indonesia), 1.1, (hal. 59-64). Publikasi Online: http://jurnal.upi.edu/mimbar-sekolahdasar/ 59

Rukiyati dan Zuchdi. 2016. Buku Filsafat Ilmu. Yogyakarta: UNY Press

Syamsi, Kastam dkk. 2013. model pengembangan buku ajar membaca berdasarkan pendekatan harga bagi siswa smp. cakrawala pendidikan 2.1

Zaprulkhan. 2016. Filsafat Ilmu: Sebuah Analisis Kontemporer. Jakarta: PT Raja Grafindo Persada. 